\title{
Towards Headship: \\ Developing Leadership and Management Skills in an Italian University Master Course*
}

\section{Giovanna Barzanò ${ }^{1}$ - Giovanni Moretti ${ }^{2}$}

${ }^{1}$ UCL Institute of Education - London (UK) - MIUR (Italy)

${ }^{2}$ Università degli Studi Roma Tre - Department of Education (Italy)

doi: 10.7358/ecps-2015-011-barz

giovanna.barzano@istruzione.it giovanni.moretti@uniroma3.it

\section{VERSO LA DIRIGENZA SCOLASTICA: SVILUPPARE LE CAPACITÀ DI LEADERSHIP E MANAGEMENT IN UN MASTER UNIVERSITARIO ITALIANO}

\section{Abstract}

This article reports on an exploratory qualitative study undertaken with the students of the tenth edition of the "Leadership and Management in Education Master Course" (LMEMC) held in Italy by the Department of Education of the University Roma Tre and attended by educational professionals from Greece and Italy, in prevalence aspiring to career improvement and new leadership roles. The study is part of an in-depth self-evaluation process aimed at updating the course activities and exploring professional adult learning. Our data consists of 65 written interviews, undertaken with student-teachers and focusing on their motivations and their positive and negative expectations towards leadership roles. After referring to the international debate on leadership preparation and development, we situate the LMEMC looking at: (a) the context of Italian HE postgraduate studies; (b) the context of educational leadership preparation and development in Italy and in Greece; (c) the course design and delivery strategies. We then describe the methodologies and

* This article is the outcome of the collaboration of the authors. However, in order to ascribe responsibility, we declare that the "Introduction» and the "Concluding remarks» are co-authored, G. Barzanò wrote $\$ \$ 2,4,6.2$, and G. Moretti wrote $\$ \$ 3,5,6.1$. 
research tools employed and draw from our results some hints for possible new developments in the LMEMC and in leadership preparation activities. Our data also allows us to reflect on the benefits of sustainable self-evaluation processes of adult learning activities.

Keywords: Adult learning, Headship preparation, Leadership development, Postgraduate studies, Teacher professional learning.

\section{INTRODUCTION}

We report here on a qualitative study undertaken with 65 student-teachers attending the tenth edition of the international second level Leadership and Management in Education Master Course (LMEMC) held in Italy by the Department of Education of the University Roma Tre and attended by Italian and Greek educational professionals, in prevalence aspiring to career improvement, headship or new leadership roles. The study is part of an indepth self-evaluation process aimed at understanding how to improve and better contextualise the provision of LMEMC. This is an already successful course, that in terms of enrolment and impact has achieved a leading position within the national scenario of master courses concerning educational leadership.

After a quick reference to how preparation to leadership roles is problematised in the international debate, we briefly situate LMEMC following a twofold perspective, looking at: (a) the context of Italian Higher Education (HE) postgraduate studies and their recent developments, and (b) the context of educational leadership preparation and its developments, both in the Italian and in the Greek system. We sketch the history of LMEMC, its origins and underpinning assumptions and delineate its design in terms of delivery strategies, contents and activities. We then describe our study, the methodologies and the research tools employed.

Finally we make sense of our data and draw some hints for possible new developments in LMEMC future editions. We focus on the results of the study to figure out areas of improvement in the course design and delivery, but we are also interested in exploiting the results to reflect on the benefits of sustainable self-evaluation processes of adult learning activities, which go beyond customer satisfaction templates.

We highlight the opportunities that an established university master course, with a consolidated history can offer to explore the processes of adult learning reaching new awareness. 


\section{DEVELOPING NEW EDUCATIONAL LEADERS: A GLOBAL CONCERN}

Preparation to leadership roles, access to headship, and leaders' professional development are core concerns in educational systems all around the world and have today a high position in the political agenda of most decision makers. As OECD (Pont et al., 2008) observes, since the mid-1990's training and development for school leaders have been introduced or strengthened in almost all countries, using a variety of approaches.

In Europe, the Council of European Union (2013, pp. 1-6) has recently devoted an important meeting to educational leadership. In the meeting's formal conclusions, educational leaders were acknowledged as «major players in forging effective links between different levels of education and training, families, the world of work and the local community, with a common aim of raising learner attainment». It is also stated that «Educational leadership calls for a range of highly developed competences underpinned by core values», thus staff occupying leadership positions «need to possess or acquire, as well as regularly update, the necessary competences for such positions». Moreover, the profession of leaders should be made more attractive, besides the rest, by «exploring and developing attractive forms of introductory training, early career support and continuous professional development for educational leaders». The Council's call for attention resonates with the concern of European professional institutions (EFEE, 2012; ETUCE, 2012) and governments, and results in a variety of initiatives and in a growing debate, as the international literature evidences.

Different, parallel causes underpin the increasing interest in leadership development, an issue that has suddenly become a core focus of education systems only in the 1990's, after having attracted very little attention for long. On the one hand a main reason that has induced governments to promote leadership as leverage for school improvement is likely to be the evidence of the relevant variation in the countries' educational performance, brought to light by international organisations such as IEA, OECD ${ }^{1}$ (Wallace et al., 2011). To other extents the dramatic shifts to forms of site-based management that started to develop as a transnational trend in the 1980's and 1990 's has caused a transformation in the perceived role of the headtecher,

1 IEA (International Association for the Evaluation of Educational Achievement), since its foundation in 1958 it has conducted more than 30 large scale surveys on educational achievement. OECD (Organisation for Economic Cooperation and Development) is a major actor in the field of world educational assessment with the PISA (Programme for International Student Assessment). 
whose job is implying an increasingly broad range of new skills (Brundrett $\&$ Crawford, 2008). Moreover the turbulence of the times and the demands of the social environment make headteachers' professional life characterised by "disorderliness and unpredictability" and engender almost insurmountable challenges, thus underlining the need for a rigorous and effective preparation (Clarke \& Wildy, 2010, p. 8) integrated in a continuous, life-long learning process (Nicolaidou, 2008).

In fact the performance of educational leaders is under the microscope, expectations from diverse sources arise, together with pressure from multiple accountabilities (Elmore, 2008; Moos, 2011; Scheerens, 2014). Besides being able to cope with accountability demands (Barzanò, 2011), being a school leader means demonstrating «many qualities, skills and traits, including resilience, persistence and emotional and contextual intelligence» (Earley, 2013, p. 138) and continuously updating them.

The hectic landscape of educational leadership and the needs for preparation and continuous development it implies, are reflected in a variety of initiatives and nurture lively discussions, where sometimes contradictory views are expressed. Some countries have put in place specific leadership programmes - either pre-service, induction or in-service - to follow OECD's (2008) classification. Some have national compulsory leadership qualifications. Some have even created national centres for leadership, while others rely on Universities qualifications or private partnerships. A meaningful example is the National College for School Leadership (NCSL) founded in 2000 in England ${ }^{2}$ (Barzanò, 2008; Bush, 2008; Wallace et al., 2011), probably «the most significant global initiative for leadership development" (Bush, 2008, p. 73), with a prominent impact on the Anglophone world. The debate that has developed across the years on NCSL and the National Professional Qualification for Headship (NPQH) ${ }^{3}$ is interesting: it mirrors the dialectics between two different components of leadership preparation and development. On the one hand there is a more technicalrational trajectory that assumes a "mechanistic» reality where change can be predicted and control centrally maintained through simple cause-effect manipulations. On the other hand, the complexity thinking trajectory emphasises non-linearity, unpredictability and dynamic relations (Bates, 2013).

2 The College original the mission to supervise and further enhance educational leadership development initiatives. From September 2009 it was renamed the National College for Leadership of Schools and Children's Services (NCLSCS) to reflect an extension of its remit.

3 The NPQH, today run by NCSL but acivated in England before its opening, has become a compulsory requirement to access headship in England in 2004. 
Education systems in other countries and in several US states (Turnbull et al., 2013; Walker et al., 2013) have opted for strong national frameworks of leadership preparation and centrally managed development, similarly to NCSL yet none has the breadth of its scope. As has been the case for NCSL (e.g. Bolam, 2004) these initiatives are often criticised for their technical rational emphasis, which appears unjustified, particularly when research on the direct impact of leadership on student learning shows uncertain results (e.g. Scheerens, 2012; Earley, 2013a and 2013b). In fact they risk to become the vessel of a government's discourse strategy, which gives primacy to leadership development as a means for implementing reforms and results in forms of «institutionalised governance» (Gunter \& Forrester, 2010), in a sort of acculturation, which lowers the intellectual challenge, rather than engaging participants in the production of knowledge (Wallace et al., 2011).

In countries where lighter national frameworks and standards are in place, university qualifications are often requested/desired. Universities have here a more crucial impact and a relevant responsibility in leadership preparation and development. As OECD (2015) underlines, 92\% of the headteachers participating in the TALIS 2013 study ${ }^{4}$ have a degree. In Italy, where holding a degree is a longstanding compulsory condition for those aspiring to heaship, the same study demonstrates an increase of postgraduate degrees $(+.3 \%)$ and a recent research (Cavalli \& Fisher, 2012) claims that about $9 \%$ of leaders hold a postgraduate degree. In fact since 2008 (DPR 240), the attendance of master courses focusing on subjects relevant to leadership roles is encouraged, and applicant headteachers get advantages over other competitors if they have a master degree. A similar situation concerns Greece, where holding a master degree, possibly awarded abroad, grants a better position in the list of aspirants to headship. In several countries, as is the case of Italy, universities become key actors, although not alone, in leadership preparation and development. They hold a considerable degree of freedom in deciding how to organize their proposals, balancing constraints, opportunities and principles. LMEMC is a case in point in this respect.

4 Teaching and Learning International Survey (TALIS) is a recurrent study promoted by OECD to invistigate the teacher condition across countries. The last edition of the study was undertaken in 2013 (OECD, 2014). 


\section{Situating LMEMC as a AN AdVANCED Vocational COURSE: THE ITALIAN HE POSTGRADUATE COURSES AND THE SCHOOL AUTONOMY LANDSCAPE}

LMEMC's activities can be better understood considering a twofold perspective: the recent developments of Italian HE postgraduate programs and the shifts occurred in the state education system in particular with regard to school autonomy and access to headship and teacher and leader professional development. Since LMEMC is today a master course attended by a relevant percentage of Greek students, we will also make a brief reference to the context of access to headship and leader and teacher professional development in Greece.

University master courses have a relatively young history in the Italian HE system, where they have been introduced in the academic year 2001/02, within the framework of the Bologna process. They are the second most advanced degrees after doctorates and are part of postgraduate studies together with other kind of academic courses. They are regulated by Law 4, 1999 / Decree 509/99 which states that in order "to achieve a masters degree, a student must have earned at least 60 credits (CFU), equivalent to 1,550 hours of work and one year of full-time study» (art. 7) ${ }^{5}$.

Universities are free to plan the courses they decide and have considerable autonomy - although in a nationally regulated framework - in defining their admission criteria and their organization, as well as the choice of learning contents and delivery methods (presence, distance or blended).

From 2001/02, enrolment trends have varied: after a steady growth until 2010/11, from then on there has been a decline. Several studies have tackled the development of university master courses in Italy in the last decade. For instance CENSIS (2007) ${ }^{6}$ in a survey concerning the full range of national master courses in three subject areas - economic-managerial, scientific-technical and socio-humanistic - highlights a high turnover rate of the courses offered, with more than $30 \%$ new entries in 2006 and several withdrawals. In this scenario Universities face uncertainties in planning their postgraduate programs. Yet they have gradually become aware that master studies represent

5 There can be two levels of courses, according to the admission criteria: registration to first level courses requires a three-year bachelor's degree, while for second level courses a second level degree is required or an «old system» degree (awarded before the 1999 reform). Thus Italian university second level master degrees, in particular, should not be confused with master degrees awarded by universities in most Anglo-phone countries, which correspond to Italian second level degrees. There are however private companies that call their training activities "master courses» or "master classes» to mean that they intend to develop advanced and specific skills, but they clearly have no links with university postgraduate studies.

6 CENSIS, 2007: 41st Annual report on the social situation of the country, pp. 87-165.

ECPS Journal - 11/2015

http://www.ledonline.it/ECPS-Journal/ 
an important area of $\mathrm{HE}$, which should be the object of a careful design in order «to respond to more specific and advanced needs for qualifications in the various domains and professions. Hence the risk (already present) of too much supply, too fragmented, not resonating with the needs for professional development and high specialization» (Cambi, 2009, p. 104).

The ups and downs of university master courses on educational leadership and management parallel to LMEMC, offer a meaningful example of what happens in a specific field. Following the Ministry of Education (MIUR) database, in 2012/13, 9 master courses concerning educational leadership are activated and 6 out of 9 are based in Rome. They account for 369 students, 50 (13\%) of whom foreign. These master courses have different histories and their survival time ranges from 2 to 10 years, with an average of 5.4 years. Over a time span, several similar courses have even disappeared soon after having been established, having completed no more than one or two editions. In the period 2008-2011, when national open competitions to recruit headteachers were launched and applicants were interested in achieving professional qualifications, 21 master courses were launched, but disappeared soon after. In the national context of master courses on educational leadership LMEMC has peculiar characteristics, having completed the highest number of editions (11) and being the only one to be attended by Italian and international students, i.e. Greek.

In order to better understand the background of our study it is important to briefly focus on the institutional environment surrounding the students who enrole in LMEMC, i.e. the Italian and Greek educational professionals, aspiring to headship with their formal and informal learning needs.

The Italian landscape of education, from the pre-primary to the uppersecondary levels has recently undergone a dramatic transformation due to the introduction of school autonomy (DPR 1999/275), implying a new status and new demanding tasks for school leaders and confronting schools with difficult educational challenges (Domenici, 2011; Serpieri, 2012; Grimaldi \& Serpieri, 2014; Petrolino \& Giannelli, 2014). In this context however the recruitment of headteachers continues to follow a longstanding tradition of national open public examinations, which, despite being now organised on a regional level, have only gone through minor changes over the years. Since headship is the only official form of career improvement available to teachers, it is highly appealing in Italy, unlike in most countries, where a worrying shortage of qualified candidates is avowed (Gronn \& Lacey, 2004; MacBeath, 2011). Every time an open competition is launched, crowds of applicants register (Grimaldi \& Barzanò, 2012) ${ }^{7}$. Several Italian teachers

7 The last open competition, launched in 2011 (DDG 13/07/2011), received 42,158 applications for 2,386 positions. Experienced teachers (five years) with a second level degree 
thus enrol in master courses of their like (but consistent with the subjects concerning headteachers' role) before taking part in their open competition, in the hope of passing the tests and being included in the rank of "winners» where their master degree will allow them to advance. However, since this opportunity appears statistically rather remote, they want to make sure they are not wasting time and money and make careful choices in order to select the most attractive and best quality courses.

In Greece headteachers are also centrally appointed, but they do not have to pass any national exam, once they have at least 8 years experience they are included in a list. Recent Eurydice figures (EACEA, 2013) underline, how Greece is one of the very few European countries where no training is requested to access leadership but only teaching and administrative experience are considered. Nor leadership development is to any extent organised by the Ministry ${ }^{8}$. Even more clearly than their Italian counterparts thus, Greek teachers achieve formal benefits when they attend a master course and get a degree. However like the Italians, once they decide to invest their money, effort and time, they are particularly careful to the quality of the learning experience they choose.

This overview in the institutional underpinning of LMEMC, both from the perspective of the hosting/providing institution and from that of the target students/professionals, highlights some of the challenges that have characterised the design and development of the course and how it was conducted during its eleven editions. In the next pages we describe the assumptions, the contents and the strategies put in place by the LMEMC to tackle

(more than 5 years of study) are entitled to apply to participate in open competitions when they are launched. Applicants are confronted with three levels of progressive screening: first a multiple choice test, then a written test with open ended essay-like questions and finally an oral interview. Those who go through the three steps (in the last competitions about $5 \%$ of the original candidates) are put in a rank and are selected, if they reach a good position. Having academic master degrees and other titles is a great help to allow for better positions. Once one has a job as a headteacher the Ministry through its regional departments provides compulsory induction activities, supported by individual mentors. According to a new legislation (Law $128,2013)$, flagged up as a main innovation, future heads will attend their induction at the National School of Public Administration.

8 As Gkolia and Brundrett (2007) observe, leadership training in Greece has been undeveloped due to the centralized nature of the education system since the main responsibility of a school leader in a Greek school is to implement ministerial directives and to coordinate the activities of teaching staff. Even if the notion of headship is shifting and broadening, centralistic tradition still prevails (Thody et al., 2007). Recent reforms have involved managers in the civil service domain (Law 3467, 2006), but have failed to touch educational leadership. Yet following the Greek legislation (Law 3848, 2010) Greek teachers who attend postgraduate studies, particularly if abroad in a foreign language, are entiltled to additional score which make them advance in the headship list. 
these challenges and find a balance between different constituencies and interests, through appropriate negotiations.

\section{BUILDING LMEMC ACROSS A DECADE: THE COURSE DESIGN AND ITS DEVELOPMENTS}

The first edition of LMEMC was launched in the academic year 2003/04. A few crucial overarching principles drove the course design and planning, which were set up by a steering committee composed of academics and highly experienced practitioners in the field of education and educational administration. They can now be re-read as follows:

- Firstly, a vision of professionalism was prioritised, based on the exercise of reflective judgement, drawing on wide repertoires of knowledge and skills, developing from experience, seeing practice as a possible source of valid theory (Schon, 1983; Goodson, 2003) and valuing experiential and informal lerning (Zhang \& Brundrett, 2010).

- Secondly, a clear intention was expressed to opt for dynamic learning approaches, where opportunities for horizontal and vertical knowledge (Bernstein, 1999) were intertwining. The idea was to create a learning community, which could become a site for knowledge creation where the contribution of a variety of experts could be treasured together with evidences from the participants' experiences.

- Thirdly, it was deemed important to shape the course pedagogy so that it could offer emblematic learning experiences the way that Keddie and Lingard (2013) have recently conceptualised as "productive pedagogies», making reference to a model that embeds the principles of equity and justice within its pedagogical process, offering insights into models such as democratic leadership for equity (Gronn, 2002; Woods \& Roberts, 2015).

- Fourthly, the need to privilege a dynamic and multidimensional perspective (Gertz, 2009) was stressed in order to make sense of the notion of leadership in context, looking at schools as organisational entities from a variety of view points, ranging from socio constructivism, to micro-politics (Barzanò \& Grimaldi, 2013), to complexity theory, understanding schools as deeply complex organisations where headteachers struggle with a wide ambit of responsibilities (Clarke \& Wildy, 2010). This without neglecting managerialistic, techno-rational approaches, but making sure that course participants could explore and master them, while being well equipped with caution and critical thinking (Bolam, 2004). 
Finally, the mapping of leadership "geography» was deemed relevant, considering the macro-levels of leadership contexts, and underlining headteachers' need to position their job in the global landscape, «not just to help others understand and mediate such effects, but because it impacts upon the work of themselves and of their profession» (Bottery, 2006, p. 20).

In the light of the assumptions above the course intended to recruit student-professionals at national level, to offer them a learning experience which could combine intellectual challenges, together with professional and practical development, drawing on: a careful selection of contents offered by distinguished national and international scholars and highly experienced practitioners through tailor-made contributions, a variety of activities delivered through blended strategy and supported by tutors monitored practical experiences, including skill self analysis. This comprised a set of thematic modules supported by self-assessment tools for individual online learning, a module of traineeship to be implemented in certified schools, two semi-residential seminars and a final examination session face to face. The course had therefore multiple venues: most of the activities were home-based, the traineeship could be attended in any national school certified by the master committee, at participants' own convenience, finally the two semi-residential seminars and evaluation session were held in the Roma Tre University premises.

The first edition of LMEMC (2003/04) clustered contents in three subject areas: (a) culture and theories, including the development of models of situational leadership and their effects on the organizational and relational dimensions; (b) the institutional framework, including the new legislation on school autonomy and its implications; (c) leadership in action, including learning centred leadership and reflections on the psychological components.

The learning environment was characterized by the flexibility of spaces and times typical of distance learning courses and the modular organization of teaching (Domenici, 2009). The Moodle platform (e-mail, forum, chat, exchange files and resources, etc.) with its integrated functions supported by expert tutors promoted the development of a virtual community of students in touch with one another and with their teachers and tutors. It also made easily available self-assessment and evaluation tools to enhance individual learning.

In its first five editions the course reinforced its original structure and maintained a stable attendance with 15-25 participants each year. Among them small groups of Greek students started to enrol in 2006. Year 2007/08 witnessed important events which originated major shifts in LMEMC's design and organisation. A Memorandum of Understanding (MOU) was signed between LMEMC and a professional association attached to a main national union, PROTEO-CGIL. Soon after a further MOU followed with a Greek association. Both agreements established special conditions for 
the associations' members participation in LMEMC future editions and welcomed delegates from their members to take part in the planning and cooperate in the new design. As a consequence a dramatic increment of attendance occurred, with more than 200 applicants in the 2007/08 edition. These new partnerships were later on (2013) complemented with the participation of LMEMC in the European Policy Network on School Leadership (EPNoSL). Extending partnerships was a means of bringing in new students, but also constituted the beginning of a new phase, which led to reshape LMEMC and to a broaden its scope, enhancing its function of site of knowledge production in various ways. The face-to-face semi residential seminars, where distinguished international scholars were invited, became public events attracting large audiences. A case in point was the 2013 conference on Leadership in Latin Countries co-organised with EPNoSL and hosting experts from 15 countries. Important publications were also produced, including the volume Leadership educativa e autonomia scolastica (Domenici $\&$ Moretti, 2011) derived from the online modules used in the first editions and soon became a national leading pubblication in the field.

Since 2010 a new course design was adopted, with revised contents and modules and a new set of activities, where more emphasis was put on the observation of leadership in action (field work and job shadowing). The model sketched below (Figure 1) illustrates la structure of LMEMC, with the five content modules (the five small segments) and the activities (the loops).

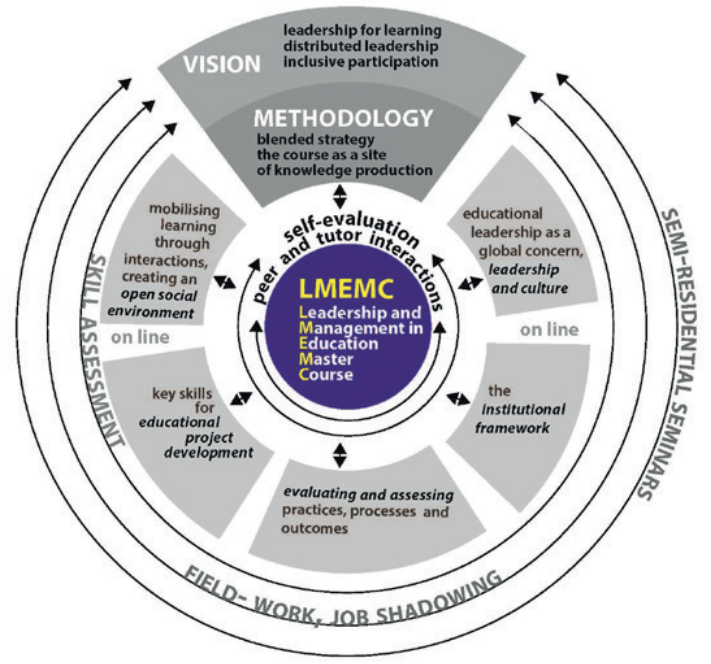

Figure 1. - LMEMC's design: contents and activities. 
The new organisation represented in Figure 1 was complemented by a shift in the course participants' composition, with an increment of the Greek component. This new scenario stressed the need for the self-evaluation which is at the centre of our study.

\section{The Self-Evaluation Qualitative Survey (SEQUAS)}

\subsection{The study}

The SEQUAS study was conceived and implemented during the tenth edition of LMEMC with the aim of exploring the developmet of the project through the lenses of its participants, analysing their motivations and understanding to what extent their needs were tackled by the course activities and how the learning environment could be updated and improved.

All the course editions had been submitted to regular monitoring and assessment, and several accounts and studies concerning the experience had been published or discussed in international conferences (e.g. Moretti, 2010 and 2012; Moretti et al., 2012). However, ten years after the start, the need of evaluating the experience emerged, underlined by the growing acknowledgements on the part of participants and the broadening of the international component. It was deemed interesting to go beyond the standardised customer satisfaction tools, to try and dig into the students' experience to gather richer accounts, in order to take a more vivid picture of how the learning process was developing and how they expected it to have an impact on their professional learning and life. The survey was also seen as a means to explore further possibilities to be included in the course activities, substancial self-reflective exercices that could at the same time be learning opportunities for the participants, as well as data gathering for the course leaders. We also intended to start feeding a research data-bank on professional adult learning experiences, as they are seen "from the field", with the eyes of learners who are commited to develop themselves and invest personal and material resources in a concrete adventure, such as a master degree is.

A written interview-questionnaire was designed, consisting of two parts. The first targeted background information, professional experience and personal details. The second consisted of five simple open questions, which were presented as a driving structure to develop a narrative on individual experiences and perceptions. Questions 1-2, concerned the expectations on the course and its expected future impact. Asking these questions in the middle 
of the course was, in our opinion an effective strategy to have meaningful, fresh information on how things were going:

1. Could you tell us about your expectations with regard to your experience in this master course?

2. What impact do you think this experience will have on your knowledge approach and on your present and professional practices?

Questions 3-4-5 intended to investigate the imagined future in order to better understand learning needs and perceived fragilities.

3. Thinking of the headteachers's job which aspects of it do you find most atractive?

4. Thinking again of the headteacher's job, which aspects of the job do you think would elicite your concern and resistance?

5. If you had to think of your professional development as a head what kind of activities and experiences would you like to be involved in?

The questionnaire was introduced by a detailed description of the aims of the survey, clarifying what the expectations on the respondents were, providing examples and guidelines. The introduction, was a substancial component of the tool and intended to motivate respondents in the task of making sense of LMEMC as participants through their reflecting-writing. Questionnaires were signed and identified: their compilation was presented as a self-reflective activity, which was part of the course experience, although not compulsory. Our data thus consisted of described perceptions. We believe that they represent reliable pictures of respondents, in the assumption that «Perceptions and beliefs alone may determine behaviour on their own» (Bottery et al., 2013, p. 47).

\subsection{The respondents}

Participants in the SEQUAS study were 43 Greeks (resp. rate 86\%) and 22 Italians (resp. rate 71.8\%), 63.1\% women and 36.9\% men. Most of them were permanent teachers in upper $(29.2 \%)$ or lower $(21.5 \%)$ secondary schools. Primary/pre-primary school teachers were $24.6 \%$. They were experienced professionals, with an average of 17.9 years on the post. Some Greek participants temporarily held the role of headteacher $(9.2 \%)$ or deputy heads $(6.2 \%)$, while there was only $1(1.5 \%)$ Italian headteacher and $2(3.0 \%)$ deputy heads. Almost half of the participants (47.9\%) were engaged in one or more middle magement assignements. Their seniority is mirrored in their 
age: the average age is 43.5 , with the Italians slightly older (45.6) than the Greeks ( 43.4 years). The largest age group is $46-50$ years for both the Greeks $(18.5 \%)$ and the Italians $(10.8 \%), 20 \%$ of respondents are over 50 and only $18.5 \%$ are under 35 .

\subsection{Data collection strategy}

The interview questionnaire was administered in the middle of the course, when participants were familiar with its contents and methologies, but still far from the final degree. Elaborating the questions and producing individual reflective-writing, was part of the course assignements. Yet, SEQUAS participation was not made compulsory, in order to have more motivated respondents.

The choice of the written interview-questionnaire was tailor-made for the characteristics of the target group. The nature of the task, required trust and confidence: the positive rapport between course leaders, tutors and participants was an important condition to prevent misunderstandings in the question-answer process. The context of the cross-cultural interview was made clear drawing attention to the task of producing information which was going to be used across different cultural and national boundaries (Ryen, 2002). Taking into account the transnational character of our survey, the introduction to the interview, the guidelines and the questions were first drafted in English and the text was later translated into the native language of the recipients (Greek and Italian). Our analysis was conducted in Italian. Greek texts were translated into Italian by educational experts. Back translation was used to verify the texts' consistency and faithfulness.

\subsection{Data and data analysis}

The SEQUAS excercice produced 65 Italian texts, where the proposed questions were answered. As mentioned above, about a fifth of the students (20.8\%) decided to withdraw from the survey.

Even at a first sight a dramatic variation in the degree of elaboration of respondents' production was evident: the length of the texts ranged from 238 words, to 3271 , with some $40 \%$ of substantial contributions, rich in contents and reflective descriptions (31 contributions had more than 1000 words) and some $15 \%$ of only essential answers (11 contributions with less than 300 words). Such a gap was higher than we expected, although not totally unattended. In any case it discouraged us from engaging in any 
«participant profile» exercice in our analysis. We rather opted for a two-step analysis which developed as follows:

a. A set of first level categories was generated, based on the full body of the data collected and following the topics introduced by the questions. This first level analysis allowed us to derive an overview and to select the most meaningful contributions (independently from words' number).

b. A selected group of 33 completed questionnaires was submitted to a more focused interpretation, using coding as analytical strategy (Strauss \& Corbin, 1990). Firstly, texts were coded creating descriptive categories (open coding). Secondly, the establishment of connections between descriptive categories has led us towards the definition of interpretative categories (axial coding) and the identification of core categories (selective coding). The headings in paragraph 6.2 («Key issues») below have been constructed using the core categories that have emerged through this methodology.

The following paragraph provides an overview of our first level analysis.

\section{UNDERSTANDING THE LEARNING OF LEADERSHIP AND MANAGEMENT SKILLS IN LMEMC}

\subsection{Overview}

Our first level analysis, was conducted on the full body of texts/answers of the 65 respondents: a synoptic overview is provided by Table 1 . It must be considered that the headings we present in the synopsis, do not derive from any previous list that we submitted to the respondents, asking their degree of agreement. Rather they are the fruit of our first level coding applied to the answers to our five questions, as emerged spontaneously in the respondents' narratives.

The great majority of respondents (59) openly declared that they had decided to enroll in LMEMC, because they wanted to improve their career, have more responsibility or earn more (section A). More than half claimed to be inspired by both, intrinsic and extrinsic motivations, while 6 respondents only by intrinsic motivation and 25 only by extrisic. Greeks are more inclined to declare intrinsic motivation than Italians $(+10 \%)$. We are presented here with a group of mature professionals with a clear hope to give a boost to their career, but also committed to improve themselves. Yet a small minority seems to be only wishing to deepen their knowledge, to better equip themselves for their teaching. 
Table 1. - LMEMC students: overview of perceptions and representations (nr. $=65)$.

\begin{tabular}{cccc}
\hline Dimensions & GREEK & ITALIAN & Total \\
& STUDENTS & STUDENTS & STUDENTS \\
& $\%$ & $\%$ & $\%$ \\
\hline
\end{tabular}

(A) Motivations to enroll in LMEMC

and expected impact (Q 1-2)

Extrinsic motivations

90.9

90.7

90.7

Intrinsic motivations

68.2

58.1

61.5

Both extrinsic and intrinsic motivations

59.1

48.2

52.3

(B) Figuring out leadership: appealing aspects

(Q3)

Personal challenge and new status

with professional and social expectations

4.6

45.4

18.5

Commitment to develop learning/teaching processes in the school

36.4

26.1

Commitment to engage in human resources management

68.2

78.5

Creating a vision.

Engaging in multidimensional tasks

48.8

54.5

50.7

to develop democratic processes

(C) Figuring out headship: threatening aspects

(Q4)

Mastering the role and coping

with responsibilities

32.5

40.9

35.4

Monitoring teaching and learning processes

2.3

22.7

9.2

Interpersonal relationship and the need

for emotional intelligence

74.4

81.8

76.9

Financial resources management

18.6

31.8

23.0

(D) Dreaming of the ideal professional

development for leadership (Q5)

Learning object

67.4

72.7

69.2

Learning context

41.8

81.8

55.4

Delivery

48.8

63.6

53.8

Activities

20.9

45.4

29.2 
When we move to the perceptions of appeal and threaten of prospective leader positions (sections $\mathrm{B}$ and $\mathrm{C}$ ), an interesting evidence emerges: dealing with human resources management and personal relationships is both the most atractive and the most scaring issue, with about $70 \%$ of Greeks and Italians considering it in both areas. The Greeks appear slightly more appealed by the challenge than frigthened, while for the Italians fearful aspects prevail.

A dramatic difference between the Greek and the Italian group appears when the notion of «status» is at stake: almost half of the Italians claim they are positively interested in achieving a new status (45.4\%), while this is the case only for the $4.6 \%$ of the Greeks ${ }^{9}$. Meanwhile the responsibilities connected with the role are deemed threatening by more than a third of the respondents from both countries, with more emphasis on the part of the Italians $(40.9 \%)$.

A relevant issue, described by half of the respondents (Greeks $48.8 \%$ and Italians 54.5\%) concerns the opportunity to create a vision, to have the chance of making a difference in building a democratic society. To a certain surprise, aspects concerning the monitoring of the learning/teaching process attract relatively little attention, with respect to other dimensions and even less on the part of the Greeks. The Italians mention it as an appealing dimension in $36.4 \%$ of cases and as worring in $22.7 \%$; the Greeks respectively in $20.9 \%$ of cases were appealed and in only $2.3 \%$ were worried. Finally it is interesting to observe that financial administration worried about a fourth of respondents: $18.6 \%$ of the Greeks and $31.6 \%$ of the Italians, less than we could have expected.

In section $\mathrm{D}$ we report on the coding of the final question (5) of our set, where participants were asked to figure out an ideal professional development activity for a country school. Unlike with other questions we were slightly disappointed about the narratives concerning this question, which were not as rich as we would have expected. We coded them according to the topics that were mentioned in the descriptions, following the emphasis put on the various aspects of the activity. As the figures show, the Italians produced more detailed descriptions, with more answers touching various components and put a stronger emphasis than the Greeks on the learning context (Greeks 41.8\% and Italians 81.8\%). The «learning objects» were the most described issues (Greeks $67.4 \%$ and Italians 72.2\%) but were developed mostly formally, scarcely detailed and problematised.

9 This difference should be seen in the light of how the role of the heateacher is designed in the Greek system: as a bureaucratic position, to which teachers access mainly by seniority (Thody et al., 2007). 


\subsection{Key issues}

Reading this data is interesting to many extents. In our second level analysis we have focused on a few core issues that we found of particular interest, among them: (a) Why attending LMEMC? (b) Building democracy through school leadership; (c) Addressing the other: attractions and challenges of interpersonal relationships; (d) Improving the student learning context.

Although there is not space in this paper to fully develop an insight in each of them we briefly sketch some example.

\section{(a) Why attending LMEMC?}

Our respondents were honest and clear in describing their commitment and their goals. They are determined in their intention to improve their career and learn as much as they can, they have demanding expectations towards the course organisers. Reading their writings we also became aware of their ambitions: by attending the course they intended to achieve a valuable certificate, and also learn a broad range of competences and expand their relationships and interactions:

I expect to learn practical attitudes that will act inside me somewhat in a catalytic way, and will produce a new awareness of leadership, making me able to meet the challenges of our days. (GR 23 F)

Having studied the international practice and contexts, you achieve a new perspective that allows you to avoid some mistakes, to better understand people and sort difficulties out. (GR 24 F)

I find it relevant that in this Master you interact with other students and know a new culture, new people, opinions, ideas. You learn how educational issues are managed in a different country, you open your horizons and enrich your knowledge. (GR $27 \mathrm{~F})$

The assemblage of skills and competences that the participants would expect to learn is very ambition and could look like a mission impossible, almost a recipe for disappointment. However, by the middle of the course some of them start perceiving a real impact and describe it:

The learning I am experiencing in the master course is even more important than I expected at the beginning. It gives me the opportunity to study issues that have a significant impact, for example seeing the role of educational leaders from new perspectives that until now I did not know. (GR $35 \mathrm{~F}$ )

I realize how amazing our endless journey of knowledge is and the fact that this educational experience is just the beginning of many other challenges. I 
am becoming aware that every problem is not addressed uniquely with one solution. I feel this understanding will help me both in my current practice as well as in my future. (GR $38 \mathrm{~F}$ )

The seminar in June has been so successful, not only for its scientific quality, but also for having offered the students a possibility to establish a direct link between the authors' names and the persons. We read the paper in the teaching modules, and in the seminar we met the authors in person. (IT $5 \mathrm{~F}$ )

The evidences we collected is rich in details and nuances that highlight a variety of aspects of respondents' learning experience and how they framed its impact. As adult learners our participants are mixing up commitment to learn and surprise in front of the new knowledge they achieve and how it allows them to find new ways to make sense of their practice.

\section{(b) Building democracy through school leadership}

The two questions in the SEQUAS questionnaire generated interesting reactions that allowed us to identify several categories: they concern the figuring out of the appealing and threatening aspects of leadership. A main category concerns the aspiration to become headtecher to embody the spirit of democracy and to find the means to build a democratic community, to take care of the school as an exemplary "public space» (Fielding, 2009). From this perspective the challenges of responsibilities appear attractive, and sometimes a sense of revenge emerges, to find the means to virtually contrast with their work the bad contexts experienced in the past:

For me, what could make the difference might be winning the challenge of building a learning community, which can enact "the common good», serving the whole community. In the end being a teacher may not coincide with the simple «teaching reading, writing and arithmetic». (IT 6 F)

Aspects that fascinate me are the ability to lead a complex organization; to work to bring together the school community with the territory; the ability to engage with society at a high level. (IT $11 \mathrm{~F}$ )

I am attracted by the possibility to have contacts with people who have a vision for education (teachers) and especially by the creation of such conditions so that students can learn in a context where they can understand democracy in practice. (GR $35 \mathrm{~F})$

I think the big challenge for the headteacher is the establishing of a coherent basis of interpersonal relationships among teachers, students, parents and all those who are part of the educational context. My experience with introverted and centralised heads prompted me to look elsewhere. (GR $37 \mathrm{M}$ ) 
Valuing diversity within the group should always be a priority. As a leader I would be eager in my school to be the one, who sets the good example by showing my intelligence and diplomacy and tackling the needs of both students and teachers. (GR $11 \mathrm{M}$ )

These excerpts let us guess, a world of negative and positive experiences that results in a boost to imitate and develop the good examples observed, or, on the contrary in a wish to cancel the tracks of negative experiences with new chances. The participants' narratives are rich in examples and portraits from the field, which deserve deeper analyses. We can see how reflecting on their experience and offering their narratives support their learning (Goodson, 2003).

\section{(c) Adressing the other: attractions and challenges of interpersonal relationships}

Interpersonal relationships are a major issue of interest and a conundrum of joy and difficulties. They embody the magic of leadership, the satisfaction of being in the position to sort out conflicts and tensions, but also the anxiety of being skilled enough to find the right tones and strategies to navigate among contrasting forces. The handling of conflicts is a typical concern of leaders in most education systems (e.g. Crawford, 2012), our respondents provide detailed descriptions of it:

The most interesting aspects are the ability and philosophy of the school leader in addressing unforeseen conflictual situations. In my career, I was lucky to meet a headteacher, who resolved tensions through his interests, his humanity and his significant involvement in the everyday needs of his staff. He knew how to sort out the aggressivity of two colleagues who were poisoning the school climate. (GR $12 \mathrm{M}$ )

Observing the daily friction and interaction between parties, I realized that I like to concentrate on the way we choose to collaborate with people involved in the school's functioning. (GR 24 F)

I am struck by the leader's ability to engender confidence and trust in colleagues thanks to her experience, by her capacity to develop the potential for cooperation enacting tolerance combined with determination in dealing with all the school staff. (GR $41 \mathrm{~F}$ )

I met a headteacher who had more than experience and preparation: great communication skills that allowed him to work in harmony with both the teachers and the parents. Probably his greatest quality was his ability to listen with his closest attention to the psychological needs of people around him. (GR $43 \mathrm{~F})$ 
I am atracted by the ascendancy that a headteacher has, which allows her to interact with teachers: in this regard I can refer to strategies I observed in practice, although I must admit it is not always easy to keep calm in stormy situations that often arise when decisions must be made. (ITA $12 \mathrm{M}$ )

The school that these aspirant leaders have in mind is a stormy one. Coping with the waves and the winds is both a source of atraction and fear. Indeed being socialised to leadership roles implies a dialogical struggle, and the construction of multiple identities (Lumby \& English, 2009).

\section{(d) Improving the student learning environment}

We have seen how a relatively low number of respondents claimed that their main atraction in the leadership profession was the improvement of the learning environment: only $26.1 \%$ of the respondents. However those who mention learning issues as a prioririty in their apreciation of the profession, appear to be looking forward to innovative planning:

One of the most significant aspects of a truly innovative leadership is the support to pupils' right to learn. I like thinking of improving the quality of educational processes, coordinating the different areas of content and methodologies, developing the school apparatus into a school project. (IT $9 \mathrm{~F}$ )

I am fascinated by the design, the coordination and the management of teaching. Within the autonomy framework schools can design crosscurricular programs, involving multiple disciplines and activities. I have already worked on new learning strategies that resonate with the complexity of knowledge. (IT $13 \mathrm{~F}$ )

What I like is the headteacher's ability to inspire and make a decisive contribution to the realization of innovative actions that students and teachers are taking. The operation of schools in Greece, of course, has a rigid framework with restrictions regarding the financial resources, but there is always room for innovation for who has ideas. (GR $30 \mathrm{~F}$ )

There is agreement in the literature on the fact that «a hugely rewarding aspect of leadership is watching children grow and seeing staff develop professionally» (MacBeath, 2011, p. 108). Yet, figuring out leadership roles our respondents seem to be more attracted by adults dynamics than by students and their learning. However when they think of learning, once again they are inspired by their experience: by the wish to expand it, or on the contrary to reverse it with better projects. 


\section{CONCLUDING REMARKS}

In its twelve year-long history which started in 2003, LMEMC has offered an advanced vocational qualification to more than a thousand Italian and Greek educational professionals, becoming a national leading initiative in its field for its longstanding continuity. It has catered for a great number of professionals not only through its courses, but also by means of its knowledge production in a broader sense. It has developed learning materials which have been shared in a variety of professional contexts even beyond the course activities, it has promoted academic and professional partnerships at national and international levels, organising important events, such as international conferences, seminars and publications. In the course of these processes LMEMC has broadened its original scope, becoming an important actor in the field of school leadership preparation, both in Italy and in Greece. We have seen how the high cultural status of the course, mirrors in participants' perceptions. To this extent it represents an interesting example of how the mission of advanced vocational qualification studies can be accomplished meaningfully within the context of HE postgraduate degrees, and how a master course can even become a site of research and knowledge production. In our study involving 65 course participants light is shed on some interesting aspects of the expectations and learning needs of experienced educational professionals who are committed to improve their career and do not hesitate to invest their personal and material resources. The study drives us inside the experience of adult professional learning and its paths and also shows how valuing personal narratives can be meaningful, both as a means of enhancing reflecting learning and as a self-evaluation strategy (Goodson, 2003; Crawford, 2012).

From a variety of view points and with different emphasis, our respondents appear convincing in witnessing their satisfaction for having joined LMEMC. They consider it as an intellectual challenge which allows them to make sense of their present, as well as a learning experience that reverberates on their future. Some of them describe this adventure as intense, rich in emotions and discoveries. Aspiring to leadership roles generates feelings that need to be told and elaborated: it seems that LMEMC has provided its studentsprofessionals with opportunities to examine their experience in the mirror of new knowledge and broader perspectives, but even more could be done in this respect. Several hints arise from the data collected for re-planning and better attuning future editions of the course. Indeed joining a master course on leadership from a teaching position appears to many as reinforcing and adding colours to their dream of career advancement which is then submitted to the «selection game» (Gronn \& Lacey, 2004). Italians are more 
disadvantaged than Greeks in this respect: the broad screening they have to go through to become headteachers leaves too much space to unpredictability that of becoming a headteacher is a risky dream. These considerations let us understand that LMEMC, as other master courses, is facing a peculiar challenge. It is a highly specialised advanced course, tackling contents - such as educational leadership - belonging to a well defined area of practice and research, and for this reason it attracts very focused participants with clear extrinsic motivations to improve their career paths. Yet attending LMEMC leads many students to face the challenge of headteacher recruitment. This is a critical process in Italy, which is one of the few countries were great numbers of teachers are looking forward to competing for a few headship positions. How many of the over one thousand professionals who have attended the different LMEMC editions have been able to accomplish their dream of advancement? We know that among the former students the percentage is relevant, but we do not have so far precise numbers to celebrate. Attending the course has helped many and will help others, but will never be able to help all to reach their extrinsic target: the effectiveness of the learning experienced is only one among other contextual factors with respect to recruitment. This is where we appreciate how several respondents balanced, in their feedbacks, considerations about their different expected achievements, providing evidence of their involvement in the intellectual challenge proposed by LMEMC, describing how it was leading them beyond their initial goals. This is consistent with the course design we illustrated, in particular with its intent to privilege the development of a rich and engaging learning armosphere, rather than surrendering to more standardised forms of knowledge.

\section{REFERENCES}

Barzanò, G. (2008). Leadership per l'educazione. Riflessioni e prospettive dal dibattito globale. Roma: Armando.

Barzanò, G. (2011). School autonomy and the new «accountabilities» of European education leaders: Case studies in England, France, Italy and Portugal. Italian Journal of Sociology of Education, 9(3), 184-209.

Barzanò, G., \& Grimaldi, E. (2013). «Policy» valutative e contesti di applicazione. Caratteristiche procedurali. Journal of Educational, Cultural and Psychological Studies, 3(6), 159-189.

Bates, A. (2013). Transcending systems thinking in education reform: Implications for policy-makers and school leaders. Journal of Education Policy, 28(1), $38-54$. 
Bernstein, B. (1999). Vertical and horizontal discourse: An essay. British Journal of Sociology of Education, 20(2), 157-173.

Bolam, R. (2004). Reflections on NCSL from a historical perspective: A new set of priorities. Educational Administration and Leadership, 32(3), 251-167.

Bottery, M. (2006). Educating leaders in a global world. School Leadership and Management, 26(1), 5-22.

Bottery, M., Ngai, G., Wong, P. M., \& Wong, P. H. (2013). Values, priorities and responses: Comparing English headteachers' and Hong Kong principals' perceptions of their work. School Leadership and Management, 33(1), 43-60.

Brundrett, M., \& Crawford, M. (Eds.). (2008). Developing school leaders: An international perspective. London - New York: Routledge.

Bush, T. (2008). Leadership and management development in education. London: Sage.

Cambi, F. (2009). L'alta formazione nelle scienze dell'educazione. In P. Orefice \& A. Cunti (a cura di), La formazione universitaria alla ricerca. Contesti ed esperienze nelle scienze dell'educazione (pp. 103-109). Milano: Franco Angeli.

Cavalli, A., \& Fischer, L. (a cura di). (2012). Dirigere le scuole oggi. Bologna: il Mulino.

CENSIS - Centro Studi Investimenti Sociali (2007). $41^{\circ}$ Rapporto annuale sulla situazione sociale del Paese. Milano: Franco Angeli.

Clarke, S., \& Wildy, H. (2010). Preparing for principalship from the crucible of experience: Reflecting on theory, practice and research. Journal of Educational Administration and History, 42(1), 1-16.

Council of the European Union (2013). Council conclusions on effective leadership in education (pp. 1-6). Education, Culture, Youth and Sport Council Meeting, Bruxelles, 25-26 November.

Crawford, M. (2012). Novice head teachers in Scotland: Competing expectations. School Leadership and Management, Special Issue, 32(3), 279-290.

Domenici, G. (a cura di). (2009). Valutazione e auto-valutazione per la qualificazione dei processi formativi e-learning. Lecce: Pensa Multimedia.

Domenici, G. (2011). Leadership educativa, cultura dell'autonomia e della valutazione come contributi per il risanamento del sistema formativo. In G. Domenici G. \& Moretti (a cura di), Leadership educativa e autonomia scolastica (pp. 19-30). Roma: Armando.

Domenici, G., \& Moretti, G. (a cura di). (2011). Leadership educativa e autonomia scolastica. Roma: Armando.

EACEA - European Commission / Eurydice (2013). Key data on teachers and school leaders in Europe. 2013 Edition. Eurydice report. Luxembourg: Publications Office of the European Union. Retrieved from: http://eacea.ec.europa.eu/ education/eurydice./documents/key_data_series/151EN.pdf. 
Earley, P. (2013a). Exploring the school leadership landscape: Changing demands, changing realities. London - New York: Bloomsbury.

Earley, P. (2013b). Observation methods: Learning about leadership practice through shadowing. Journal of Educational, Cultural and Psychological Studies, 3(6), 15-31.

EFEE - The European Federation of Education Employers (2012). School leadership and governance: Lifelong learning. http:/www.educationemployers.eu/ uploads/files/efee_report_leadership_final.pdf.

Elmore, R. F. (2008). Leadership as the practice of improvement. In B. Pont, D. Nusche, \& D. Hopkins, Improving school leadership, Vol. 2: Case studies on system leadership (pp. 37-67). Paris: OECD.

ETUCE - European Trade Union Committee for Education (2012). School leadership in Europe: Issues, challenges and opportunities. Bruxelles: Trade Union Committee for Education.

Fielding, M. (2009). Public space and educational leadership: Reclaiming and renewing our radical traditions. Educational Management Administration and Leadership, 37(4), 497-521.

Getz, G. (2009). Teaching leadership as esploring sacred space. Educational Action Research, 17(3), 447-461.

Gkolia, C., \& Brundrett, M. (2008). Educational leadership development in Greece. In M. Brundrett \& M. Crawford (Eds.), Developing school leaders: An international perspective (pp. 41-57). London - New York: Routledge.

Goodson, I. (2003). Professional knowledge, professional lives. Maidenhad: Open University Press.

Grimaldi, E., \& Barzanò, G. (2012). NPM discourse, testing, and the selection of head teachers. Italian Journal of Sociology online.

Grimaldi, E., \& Serpieri, R. (2014). Italian education beyond hierarchy governance, evaluation and headship. Educational Management Administration and Leadership, 42(4S), 119-138.

Gronn, P. (2002). Distributed leadership. In K. Leithwood, P. Hallinger, K. Seashore-Louis, G. Furman-Brown, P. Gronn, W. Mulford, \& K. Riley (Eds.), Second international handbook of educational leadership and administration (pp. 1-48). Dordrecht: Kluwer.

Gronn, P., \& Lacey, K. (2004). Positioning oneself for leadership: Feelings of vulnerability among aspirant school principals. School Leadership and Management, 24(4), 405-424.

Gunter, H., \& Forrester, G. (2009). Institutionalized governance: The case of the National College for School Leadership. International Journal of Public Administration, 32(5), 349-369.

Keddie, A., \& Lingard, B. (2013). Redistribution, recognition and representation: Working against pedagogies of indifference. Pedagogy, Culture and Society, 21(3), 427-447. 
Lumby, J., \& English, F. (2009). From simplicism to complexity in leadership identity and preparation: Exploring the lineage and dark secrets. International Journal of Leadership in Education, 12(2), 95-114.

MacBeath, J. (2011). No lack of principles: Leadership development in England and Scotland. School Leadership and Management, 31(2), 105-121.

Moos, L. (2011). Educating Danish school leaders to meet new expectations? School Leadership and Management, 31(2), 155-164.

Moretti, G. (2010). A scuola di futuro con il Master in «Leadership e Management in Educazione». Journal of Educational, Cultural and Psychological Studies, 1, June, 197-202.

Moretti, G. (2012). Gli strumenti organizzativi dell'autonomia: il punto di vista degli insegnanti sui documenti. Giornale Italiano della Ricerca Educativa, $\mathrm{Nu}-$ mero speciale, 5, 112-129.

Moretti, G., Domenici, G., \& Ciraci, A. M. (2012). The Master Course in Leadership and Management in Education: Results of the monitoring and research activities. In 8th International Conference on education, Samos Island Greece, 5-7 July, 239-347.

Nicolaidou, M. (2008). Attempting a Europeanization of educational leadership: Philosophical and ideological dimensions. International Journal of Leadership in Education, 11(2), 211-223.

OECD (2014). TALIS 2013 results: An international perspective on teaching and learn. Paris: OECD. Retrieved from: http://dx.doi.org/10.1787/9789264196261-en.

OECD (2015). Education policy outlook 2015: Making reforms happen. Paris: OECD. Retrieved from: http://dx.doi.org/10.1787/9789264225442-en.

Pashiardis, P. (Ed.). (2014). Modeling school leadership across Europe: In search of new frontiers. The Netherlands: Springer.

Petrolino, A., \& Giannelli, A. (2014). An Italian perspective. In P. Pashiardis (Ed.), Modeling school leadership across Europe in search of new frontiers (pp. 107127). The Netherlands: Springer.

Pont, B., Nusche, D., \& Moorman, M. (2008). Improving school leadership, Vol. 1: Policy and practice. Paris: OECD.

Ryen, A. (2002). Cross-cultural interviewing. In J. F. Gubrium \& J. A. Holstein, Handbook of interview research: Context and method (pp. 335-354). London: Sage.

Scheerens, J. (Ed.). (2012). School leadership effects revisited: Review and meta-analysis of empirical studies. Utrecht: Springer.

Scheerens, J. (2014). Evidence based educational policy and practice: The case of applying the educational effectiveness knowledge base. Journal of Educational, Cultural and Psychological Studies, 1(9), 83-99.

Schön, R. (1983). The reflective practitionner, how professionals think in action. New York: Basic Books. 
Serpieri, R. (2012). Senza leadership: la costruzione del dirigente scolastico. Dirigenti e autonomia nella scuola italiana. Milano: Franco Angeli.

Strauss, A., \& Corbin, J. M. (1990). Basics of qualitative research: Grounded theory procedures and techniques. London - New York: Sage.

Thody, A., Zoi, P., Johansson, O., \& Pashiardis, P. (2007). School principal preparation in Europe. International Journal of Educational Management, 21(1), 37-53.

Turnbull, B., Derek, L., Riley, D. L., \& MacFarlane, J. R. (2015). Building a stronger principalship, Vol. 3: Districts taking charge of the principal pipeline. Policy Studies Associates, Inc. Retrieved from: http://www.wallacefoundation.

Walker, A., Bryant, D., \& Lee, M. (2013). International patterns in principal preparation: Commonalities and variations in pre-service programmes. Educational Management Administration and Leadership, 41(4), 405-434.

Wallace, M., Tomlinson, M., \& O’Reilly, D. (2011). Mediation of acculturation: Orchestrating school leadership development in England. Educational Management Administration and Leadership, 39(3), 261-282.

Woods, P., \& Roberts, A. (2015). Developing distributed leadership for equity and learning: A toolset for policy-makers and school leaders. European Policy Network on School Leadership (EPNoSL). Retrieved from: http://www.schoolleadership.eu.

Zhang, W., \& Brundrett, M. (2010). School leaders' perspectives on leadership learning: The case for informal and experiential learning. Management in Education, 24(4), 154-158.

\section{RiassunTo}

Questo articolo presenta gli esiti di uno studio esplorativo di tipo qualitativo svolto con gli studenti iscritti alla decima edizione del Master in "Leadership e Management in Educazione» (LMEMC). Attivo in Italia presso il Dipartimento di Scienze della Formazione dell'Università Roma Tre, LMEMC è frequentato da professionisti dell'educazione provenienti da Italia e Grecia, in prevalenza aspiranti a miglioramenti di carriera e interessati all'esercizio di nuovi ruoli di leadership. Lo studio fa parte di un elaborato processo di autovalutazione che ha l'obiettivo di potenziare le attività del corso e di conoscere più approfonditamente l'apprendimento professionale degli adulti. I dati raccolti consistono in 65 interviste scritte, condotte con studenti-insegnanti, le loro motivazioni e le loro aspettative positive o negative nei confronti dei ruoli di leadership. Dopo i riferimenti al dibattito internazionale sulla preparazione ai ruoli di leadership, il LMEMC è collocato: (a) nell'ambito di studi post-laurea in Italia; (b) nel contesto della preparazione e dello sviluppo della leadership educativa in Italia e in Grecia; (c) nel contesto della realizzazione-riprogettazione del corso. Il contributo illustra le metodologie e gli strumenti utilizzati nella ricerca e fornisce alcuni suggerimenti utili per possibili nuovi sviluppi del LMEMC e 
per la progettazione delle attività di preparazione alla leadership. Lo studio permette inoltre di riflettere sui benefici che possono derivare dalla realizzazione di processi sostenibili di attività autovalutazione nel campo dell'apprendimento degli adulti.

Parole chiave: Educazione degli adulti, Preparazione dei dirigenti scolastici, Studi post-laurea, Sviluppo della leadership educativa, Sviluppo professionale degli insegnanti. 